\title{
Path analysis on the Determinants of Pap Smear Utilization for Cervical Cancer Early Detection in Women of Reproductive Age
}

\author{
Gesit Kusuma Wardhani'), Ambar Mudigdo²), Isna Qadrijati³) \\ 1)Masters Program in Public Health, Universitas Sebelas Maret \\ ${ }^{2)}$ Department of Onkologi, Dr. Moewardi Hospital, Surakarta \\ 3)Faculty of Medicine, Universitas Sebelas Maret
}

\begin{abstract}
Background: Cervical cancer is the fourth most common malignant cancer among women after breast, colorectal, and lung cancers. Pap smear has been recognized as an effective strategy for reducing the incidence and mortality rate of cervical cancer. This study aimed to investigate the determinants of Pap smear utilization for cervical cancer early detection in women of reproductive age using path analysis model.

Subjects and Method: This was an analytic observational study with a case-control design. The study was conducted in Cilongok and Ajibarang Sub-districts, Banyumas, Central Java, from January 3 to February 3, 2018. A total sample of 200 women reproductive age was selected for this study by fixed disease sampling. The dependent variable was Pap smear utilization. The independent variables were education level, attitude, perception on the quality health care, access to the health center, family support, peer support, and health personnel support. The data were collected by questionnaire and analyzed by path analysis.

Results: Pap smear utilization was positively and directly associated with education $(\mathrm{b}=2.63$; $95 \% \mathrm{CI}=1.77$ to $3.48 \mathrm{p}<0.001)$, perception on quality of health care $(\mathrm{b}=1.04 ; 95 \% \mathrm{CI}=0.22$ to 1.86 ; $\mathrm{p}=0.012)$, attitude $(\mathrm{b}=1.48 ; 95 \% \mathrm{CI}=0.51$ to $2.44 \mathrm{p}=0.003)$, access to health center $(\mathrm{b}=1.02 ; 95 \%$ $\mathrm{CI}=0.20$ to $1.84 \mathrm{p}=0.015)$, family support $(\mathrm{b}=1.29 ; 95 \% \mathrm{CI}=-0.22$ to $2.61 ; \mathrm{p}=0.029)$, and health personnel support $(b=2.02 ; 95 \% \mathrm{CI}=0.60$ to $3.45 \mathrm{p}=0.005)$. Pap smear utilization was indirectly associated with peer support through perception on quality health care $(b=0.66 ; 95 \%=-0.01$ to $1.33 \mathrm{p}=0.031$ ).

Conclusion: Education, perception on quality of health care, attitude, access to health center, family support, and health personnel support are directly associated with Pap smear utilization.
\end{abstract}

Keywords: Pap smear, cervical cancer, path analysis, education, attitude, perception, family support, peer support, health personnel support

\section{Correspondence:}

Gesit Kusuma Wardhani. Masters Program in Public Health, Universitas Sebelas Maret. Jl. Ir. Sutami No. 36 A, 57126, Surakarta, Central Java. Email: gesitkusuma92@gmail.com.

\section{BACKGROUND}

Up until now, cervical cancer is still a health problem of women in Indonesia in relation to the incidence and the death rate caused by it which is very high. This disease is the fourth most common type of malignant cancer, following breast, colorectal and lung cancer. In developing countries cervical cancer is in the first place (Rasjidi, 2009).
In Indonesia, it is estimated that every day, 40-45 new cases occur, 20-25 people die, meaning that every 1 hour, it is estimated that a woman died because of cervical cancer. This is because a third of cases of cancer including cervical cancer come to health care at an advanced stage where cancer cells have spread to other organs (Septadina, 2015).

Considering the weight caused by cervical cancer in terms of life expectancy, 
Journal of Health Promotion and Behavior (2017), 2(4): 359-370

https://doi.org/10.26911/thejhpb.2017.02.04.08

the duration of suffering, and the high cost of treatment, it is better if people pay greater attention to the disease and increase the preventive efforts that can be done (Bustan, 2007). According to Rasjidi (2009), if the disease is not immediately detected and treated, patients with cervical cancer-without metastasis to the lymph nodes will only have 5 Year Survival Rate (5-YSR) or survive for 5 years.

One reason for the growing development of cervical cancer is caused by the low coverage of early detection of cervical cancer, such as pap smears. Based on WHO data estimation in 2008 , only $5 \%$ of women in developing countries, including Indonesia are receiving services, whereas effective screening coverage is needed to reduce morbidity and mortality from cervical cancer is $85 \%$ (Linadi, 2013).

According to Arum (2015), pap smears can detect cervical cancer by finding premalignant and malignant processes in ectocervix and infections in endocervix with 90\% $-95 \%$ specificity and 90\% accuracy. This is one of the advantages of Pap smear tests compared to Visual Inspection with Acetic Acid (IVA) with specificity of $64 \%$ $98 \%$ and positive predictive value of $10 \%$ $20 \%$ and accuracy of $85 \%$.

According to Rokhmawati (2011), behavior is still a barrier on Female Age Fertile to perform early detection of servical cancer. The process of formation or change of behavior can be influenced by various factors both from inside and outside of the individuals.

Based on Lawrence Green (1980), behavior is determined by three main factors namely; predisposing factors (factors that facilitate the occurrence of behaviors such as knowledge, attitude, perception, education level, socioeconomic level); Possible factors (access to health services, availability of facilities and infrastructure or health facilities for the community such as puskesmas, hospitals, posyandu, polindes, and so on); and reinforcing factors (factors that reinforce the occurrence of behaviors such as the support of a husband or family, community leaders, peers, religious leaders, health workers, laws, regulations and so on).

Based on preliminary study results through interviews of 10 women who have a partner in May 2017 in Cilongok subdistrict, Banyumas regency, only 10\% of women have had pap smear due to full support from their husbands, while others have never done pap smear examination with no reason to know and have never received information about cervical cancer and papsmear. About 20\% of them are because of the cost limitation because they do not have BPJS card and have difficulty access to Pap smear examination.

Several efforts have been made by the local government of Banyumas Regency to cope with the incidence of cervical cancer, one of them is through free pap smear screening in collaboration with BPJS Kesehatan and some public health center in Banyumas Regency, but in fact this effort has not been effective yet increase the active role of women of childbearing age in Banyumas Regency in making preventive efforts early detection of cervical cancer with pap smear method. The purpose of this study is to analyze the determinants of early detection of cervical cancer Pap smear method in women of childbearing age in Banyumas Regency ".

\footnotetext{
SUBJECTS AND METHODS

1. Study Design

This was an analytic observational study with a case control design. The study was conducted in Ajibarang and Cilongok districts, Banyumas regency, from January 3 to February 3, 2018.
} 


\section{Population and Samples}

The target population of the study was women of childbearing age. While the source population in this study was Women Age Fertile (WUS) in Ajibarang and Cilongok districts. A sample of 200 study subjects was selected by fixed disease sampling.

\section{Research Varibles}

The independent variable in this study was the perception of service quality, attitude, education, access of health service, family support, peer support, support of health worker, while the dependent variable was the pap smear use.

\section{Operational definition of variables}

The perception of service quality was defined as the response or opinion of the subject to the quality of services provided by health personnel. The data were collected by the SERVQUAL questionnaire (15 questions). The measurement scale was continuous, but for the purpose of data analysis, it was transformed into dichotomous, coded o for poor and 1 was good.

Attitude was defined as the response or the closed response of the subject to the examination of early detection of cervical cancer Pap smear method. The data were collected by questionnaire (10 questions). The measurement scale was continuous, but for the purpose of data analysis, it was transformed into dichotomous, coded o for negative and 1 was positive.

Education was defined as the highest level of formal education that has been taken. The data were collected by questionnaire. The measurement scale was categorical, coded o for $<$ Senior high school and 1 for $\geq$ Senior high school.

The definition of access to health services was defined as access or distance traveled by Fertile Age Women from home to health services to perform pap smear examination. The data were collected by questionnaire. The measurement scale was continuous, but for the purpose of data analysis, it was transformed into dichotomous, coded $\mathrm{o}$ for poor access and 1 for good access.

Family support was defined as all the attitudes and behaviors of the family in giving encouragement and attention to the subjects, both emotional, physical support, and information to perform pap smear examination. The data were collected by questionnaire. The measurement scale was continuous, but for the purpose of data analysis, it was transformed into dichotomous, coded o for weak support and 1 for strong support.

Peer support was defined as the encouragement, information, and open and positive nature provided by peers in both emotional, real, and information support so that the subjects are willing to perform a Pap smear examination. The data were collected by questionnaire. The measurement scale was continuous, but for the purpose of data analysis, it was transformed into dichotomous, coded o for weak support and 1 for strong support.

Health personnel support was defined as encouragement, information, and positive attitude provided by health personnel, both emotionally, physically, and information support so that the subject are willing to perform the pap smear examination. The measurement scale was continuous, but for the purpose of data analysis, it was transformed into dichotomous, coded o for weak support and 1 for strong support.

The use of Pap smear test was defined as a form of action performed by WUS in the form of early detection of cervical cancer with Pap smear method within the last 1 year. The measuring tool was a register book of Pap smear. The measurement scale was categorical, coded o for never done the pap smear examination and 
1 for have done a pap smear examination in last 1 year.

\section{Data Collection}

The variables of perceptions of service quality, attitude, family support, peer support, health personnel support were measured by questionnaires. While the variables of education, access to health service and the use of Pap smear test were measured by checklists.

The research instruments were questionnaires and medical records. The validity test in this study was conducted on 20 women of childbearing age in Cilongok district. The face validity has been consulted to prof. Dr. Ambar Mudigdo, dr., Sp. PA (K) and Dr. Eti Poncorini Pamungkasari, dr., M.Pd.

The reliability test in this study was conducted on 20 women of childbearing age in Cilongok district. The reliability test

Table 1. Sample characteristics

\begin{tabular}{lcc}
\hline \multicolumn{1}{c}{ Variable } & n & \% \\
\hline The perception of service quality & 107 & 53.5 \\
Good Perception & 93 & 46.5 \\
Bad perception & 61 & 30.5 \\
Attitude & 139 & 69.5 \\
Positive attitude & & 68 \\
Negative attitude & 136 & 32 \\
Fertile Age Women Education & 64 & 54 \\
High & & 46 \\
Low & 108 & 7 \\
Access to Health Services & 92 & 93 \\
Good access & & \\
Poor access & 14 & 76 \\
Family Support & 186 & 24 \\
Good support & & \\
Peor support & 152 & 90 \\
Good support & 48 & 10 \\
Poor support & & \\
Health personnel support & 180 & 20 \\
Good support & & \\
Poor support & & \\
\hline
\end{tabular}

was done by calculating the total-item correlation and Cronbach alpha.

\section{Data Analysis}

The characteristics of sample perception data on service quality, attitudes, education, access to health services, family support, peer support, health personnel support were described in $\mathrm{n}$ and\%.

The bivariate analysis was done using Chisquare test.

The data were analyzed by using path analysis, with the following steps:
a. Estimation
b. Model specification
c. Model fit
d. Model re-specification

\section{Research Ethics}

The research ethics included research approval, anonymity, and confidentiality.

\section{Univariate analysis}

$\frac{\text { RESULTS }}{\text { 1. Univariate analysis }}$


Table 2. Chi-square analysis of perceptions of service quality, attitudes, education, access to health services, family support, peer support, support of health workers with the use of pap smear tests

\begin{tabular}{|c|c|c|c|c|c|c|c|c|c|}
\hline \multirow{3}{*}{ Variable } & \multirow{3}{*}{ Category } & \multicolumn{4}{|c|}{ Pap smear use } & \multirow{3}{*}{$\mathbf{O R}$} & \multicolumn{2}{|c|}{$95 \% \mathrm{CI}$} & \multirow{3}{*}{$\mathbf{p}$} \\
\hline & & \multicolumn{2}{|c|}{ No } & \multicolumn{2}{|c|}{ Yes } & & \multirow{2}{*}{$\begin{array}{l}\text { Lower } \\
\text { Limit }\end{array}$} & \multirow{2}{*}{$\begin{array}{l}\text { Upper } \\
\text { Limit }\end{array}$} & \\
\hline & & $\mathbf{n}$ & $\%$ & $\mathbf{n}$ & $\%$ & & & & \\
\hline \multirow[t]{2}{*}{$\begin{array}{l}\text { Perception of } \\
\text { service quality }\end{array}$} & $\begin{array}{l}\text { Poor } \\
\text { perception }\end{array}$ & 45 & $48.4 \%$ & 48 & $51.6 \%$ & 3.07 & 1.67 & 5.63 & $<0.001$ \\
\hline & $\begin{array}{l}\text { Good } \\
\text { perseption }\end{array}$ & 25 & $23.4 \%$ & 82 & $76.6 \%$ & & & & \\
\hline \multirow[t]{2}{*}{ Attitude } & Negative & 59 & $42.4 \%$ & 80 & $57.6 \%$ & $3 \cdot 35$ & 1.60 & 6.98 & $<0.001$ \\
\hline & Positive & 11 & $18 \%$ & 50 & $82 \%$ & & & & \\
\hline \multirow[t]{2}{*}{ Education } & Low & 44 & $68.7 \%$ & 20 & $31.3 \%$ & 9.30 & 4.71 & 18.36 & $<0.001$ \\
\hline & High & 26 & $19.1 \%$ & 110 & $80.9 \%$ & & & & \\
\hline \multirow[t]{2}{*}{ Access } & Poor & 46 & $50 \%$ & 46 & $50 \%$ & 3.50 & 1.90 & 6.44 & $<0.001$ \\
\hline & Good & 24 & $22.2 \%$ & 84 & $77.8 \%$ & & & & \\
\hline Family & Poor & 69 & $37.1 \%$ & 117 & $62.9 \%$ & 7.66 & 0.98 & 59.88 & 0.023 \\
\hline support & Good & 1 & $7.1 \%$ & 13 & $92.9 \%$ & & & & \\
\hline \multirow[t]{2}{*}{ Peer Support } & Poor & 23 & $47.9 \%$ & 25 & $52.1 \%$ & 2.05 & 1.06 & 3.98 & 0.031 \\
\hline & Good & 47 & $30.9 \%$ & 105 & $69.1 \%$ & & & & \\
\hline Health & Poor & 15 & $75 \%$ & 5 & $25 \%$ & 6.81 & 2.36 & 19.69 & $<0.001$ \\
\hline $\begin{array}{l}\text { personnel } \\
\text { support }\end{array}$ & Good & 55 & $30.6 \%$ & 125 & $69.4 \%$ & & & & \\
\hline
\end{tabular}

Table 2 presents bivariate analyzes of perceptions of service quality, attitudes, education, access to health services, family support, peer support, support of health workers with the use of Pap smears. There was a positive correlation between perception of health service quality and Pap smear use $(\mathrm{OR}=3.07 ; 95 \% \mathrm{CI}=1.67$ to $5.63 ; \mathrm{p}<0.001)$.

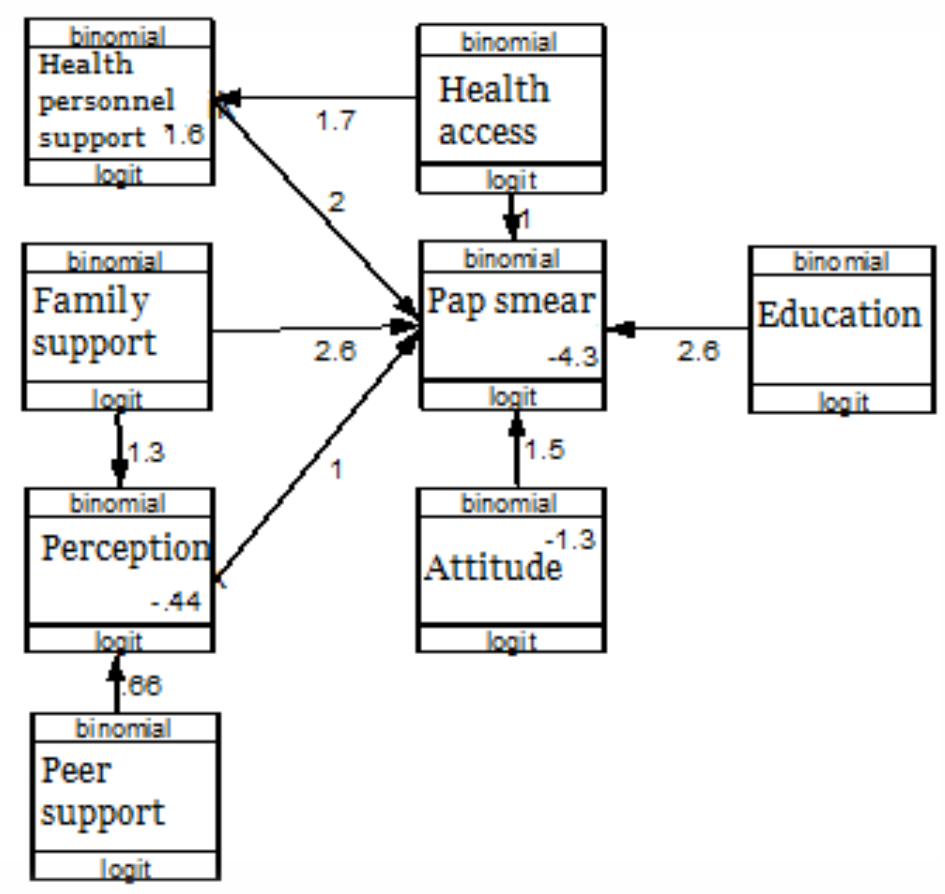

Figure 1. The specification model of path analysis 
Journal of Health Promotion and Behavior (2017), 2(4): 359-370

https://doi.org/10.26911/thejhpb.2017.02.04.08

Table 3. The result of path analysis determinant of pap smear use

\begin{tabular}{|c|c|c|c|c|c|c|c|}
\hline \multirow[b]{2}{*}{ Dependent Variable } & \multirow{2}{*}{\multicolumn{2}{|c|}{$\begin{array}{c}\text { Independent } \\
\text { Variable }\end{array}$}} & \multirow[b]{2}{*}{ b } & \multicolumn{4}{|c|}{ CI $95 \%$} \\
\hline & & & & SE & $\begin{array}{l}\text { Lower } \\
\text { Limit }\end{array}$ & $\begin{array}{l}\text { Upper } \\
\text { Limit }\end{array}$ & $\mathbf{p}$ \\
\hline \multicolumn{8}{|l|}{ Direct effect } \\
\hline Pap smear use & $\leftarrow$ & Attitude & 1.48 & 0.49 & 0.51 & 2.44 & 0.003 \\
\hline Pap smear use & $\leftarrow$ & Education & 2.63 & 0.43 & 1.77 & 3.48 & $<0.001$ \\
\hline Pap smear use & $\leftarrow$ & Family support & 2.64 & 1.21 & 0.26 & 5.02 & 0.029 \\
\hline Pap smear use & $\leftarrow$ & $\begin{array}{l}\text { Access to health } \\
\text { service }\end{array}$ & 1.02 & 0.41 & 0.20 & 1.84 & 0.015 \\
\hline Pap smear use & $\leftarrow$ & $\begin{array}{l}\text { Health personnel } \\
\text { support }\end{array}$ & 2.02 & 0.72 & 0.60 & 3.45 & 0.005 \\
\hline Pap smear use & $\leftarrow$ & $\begin{array}{l}\text { The perception of } \\
\text { service quality }\end{array}$ & 1.04 & 0.41 & 0.22 & 1.86 & 0.012 \\
\hline \multicolumn{8}{|l|}{ Indirect Effects } \\
\hline Health personnel support & $\leftarrow$ & $\begin{array}{l}\text { Access to health } \\
\text { service }\end{array}$ & 1.69 & 0.57 & 0.56 & 2.83 & 0.003 \\
\hline $\begin{array}{l}\text { The perception of service } \\
\text { quality }\end{array}$ & $\leftarrow$ & Family support & 1.29 & 0.67 & -0.02 & 2.61 & 0.055 \\
\hline $\begin{array}{l}\text { The perception of service } \\
\text { quality } \\
\text { N Observation }=200 \\
\text { Log likehood }=-397.16\end{array}$ & $\leftarrow$ & Peer support & 0.66 & 0.34 & -0.003 & 1.33 & 0.051 \\
\hline
\end{tabular}

There was a positive relationship between attitudes and the use of Pap smears $(\mathrm{OR}=3.35 ; 95 \% \mathrm{CI}=1.60$ to 6.98 ; $\mathrm{p}<0.001)$. There was a positive correlation between education and the use of Pap smears (OR $=9.30 ; 95 \% \mathrm{CI}=4.71$ to 18.36 ; $\mathrm{p}<0.001)$.

There was a positive relationship between access to health services and the use of Pap smears $(\mathrm{OR}=3.50 ; 95 \% \mathrm{CI}=$ 1.90 to $6.44 ; \mathrm{p}<0.001)$.

There was a positive relationship between family support and Pap smear use $(\mathrm{OR}=7.66 ; 95 \% \mathrm{CI}=0.93$ to $59.88 ; \mathrm{p}$ $<0.001)$.

There was a positive relationship between peer support and Pap smear use $(\mathrm{OR}=2.05 ; 95 \% \mathrm{CI}=1.06$ to $3.98 ; \mathrm{p}$ $<0.001)$. There was a positive relationship between the support of health personnel and the use of Pap smears (OR $=6.81 ; 95 \%$ $\mathrm{CI}=2.36$ to $19.69 ; \mathrm{p}<0.001)$.

Table 3 shows that there was a direct correlation between attitudes, education, family support, access to health services, support of health workers and perceptions of service quality with the use of pap smears and increased logs to perform pap smear examinations, and the relationship was statistically significant.

There was also an indirect relationship between access to health services with the use of pap smears through the variable support of health personnel and the relationship was statistically significant. There was also an indirect relationship between family support and peer support with the use of pap smears through the perceptual variables of health service quality and the relationship was statistically significant.

\section{DISCUSSIONS}

\section{The relationshiop between per- ception on the quality of health center and Pap Smear utilization}

The result of this study showed that there was a relationship between perception on the quality of health center and Pap Smear utilization. The better the quality of health 
services on Pap Smears, the greater the willingness of women in reproductive age (WRA) to perform the Pap Smear test. Research subjects stated that the quality of health services in health center was already good and proper, so WRA was satisfied with the services provided. The services include the expertise of health personnel, health personnel response/responsiveness, security guarantees of service, empathy of health personnel, hygiene, and comfortable places and service equipments.

This study is consistent with a study by Mursyida (2012), which stated that quality of service was closely related to satisfaction, satisfaction was able to provide a good foundation for behavior change and mothers' re-visit, as well as spreading the recommendation.

It can be concluded that if the quality of health services was not guaranteed, then it would affect the perception of the recipients of health services and would be a barrier to the mothers to perform a health service, including Pap Smer test.

This study is consistent with a study by Candraningsih (2011) who stated that several constraints to Pap Smear test were the mothers felt embarrassed and afraid to check their cervical reproductive organs to health personnels, and the lack of sources of information and facilities or health services for Pap Smear test. Therefore, the facility and quality of a health service was considered very important for a health service provider. If the quality of health services was good, then the perception of the recipient would be good as well, therefore, it increased the willingness of WRA to perform health services, especially Pap Smear test.

\section{The relationship between attitude and Pap Smear utilization}

The result of this study showed that there was a relationship between attitude and
Pap Smear utilization. This study is consistent with a study by Ketut (2011) about the relationship between knowledge and WRA's attitudes on Pap Smear test in Sukawati II health center. The result of the study showed that attitude was strongly related to Pap Smear test.

Sakanti (2007) also stated that all women who perform early detection of cervical cancer check-up have a positive attitude towards early detection of cervical cancer.

Based on the result of this study, it was known that most women in reproductive age were afraid of doing Pap Smears tests because they were worried about the results of the tests that may diagnosed them to have cervical cancer. There were also some mothers who feel embarrassed because the Pap Smear test required them to show their genitals part to other people. Mothers assumed that Pap Smear tests were not neccessary because the mothers did not have history of cancer. Mothers felt the need to do an early examination of cervical cancer if there were some symptoms of cervical cancer such as bleeding and vaginal discharge.

Most of the subjects of this study were mothers who worked outside the house. 16.5\% of mothers who did not do Pap smears test were working as laborers/farmers, entrepreneurs, private employees, and civil servants. Mothers assumed that they did not have free time to perform health services except services that were considered important, such as pregnancy check or did the treatment due to illness.

Regarding the positive attitudes on Pap Smear utilization, $35 \%$ of mothers were housewives, therefore, mothers have more time and opportunity to attend a health center. This suggested that the type of employment greatly affect the maternal attitudes to perform Pap Smear tests. 
Journal of Health Promotion and Behavior (2017), 2(4): 359-370

https://doi.org/10.26911/thejhpb.2017.02.04.08

Based on the description above, the researcher suggested that someone's attitude would affect the action to be performed. Attitude would give the person a basis to behave in a particular way he/she choose. Mothers who have negative attitudes tend to behave negatively, and vice versa.

\section{The relationship between educa- tion and Pap Smear utilization}

According to Dewi (2010), education can affect someone's behavior to formed lifestyle, especially in motivating the attitude to participate and also in health development. Generally, the higher a person's education, the easier it was to receive information. The result of this study showed that there was a significant relationship between education and Pap Smear utilization. The result of this study was in accordance with Green (1980) who stated that education greatly affected on health behavior. This was also in line with Handoko (2011) who stated that human's behavior was determined by his/her thinking ability. The higher the level of education and consciously also perform actions to fulfill the desires and needs.

Based on the results, it can be concluded that highly educated people would have wider knowledge than the loweducated people, therefore, they would have a better attitude towards the importance of early detection of cervical cancer, in this case was the method of Pap Smear.

\section{The relationship between access to health services and Pap Smear utilization}

The result of this study showed that there was a direct relationship between access to health services and Pap Smear utilization. There was also an indirect relationship through positive relationship between access and Pap Smear utilization through health personnel.
Based on the researcher's observation, the distance of health service facility of Pap smear test in Cilongok and Ajibarang has been reached by the community. The mileage was not too far which was 3-5 km, the highway was not damaged, and there were many available public transportations. This condition was very supportive for WRA in doing Pap Smear test.

Another factor was the support of health personnels, WRA with good access and who initially intended to perform other health services were educated and persuasive by health personnel, therefore, WRA was interested to conduct Pap Smear tests. This often happened in reality so that it can increase the coverage of Pap Smear test.

The distance of health facilities that provide affordable Pap smear test services for WRA would increase the utilization of Pap smear test, because the distance limit the ability and willingness of women to seek services, especially if the availability of transportation was limited, difficult communication, and if there was no place for services in that area.

This study is consistent with a study by Susanti (2012) which stated that there was a significant relationship between the availability of health services and behavioral test of early detection of cervical cancer. This study is consistent with a study by Rohmawati (2011) which stated that there was a significant relationship between the reachable distance to the service of early detection of cervical cancer (health center) with the behavior of early detection of cervical cancer.

Green (1980) stated that the distance and the availability of transportations were the enabling factors of an accomplished motivation. Basic Health Research (2010) reported that the ease of access and utilization of health services were related to several determinants, one of them was the 
distance of residence to health service facilities, therefore, it can be concluded that access to health services has an important effect on the occurrence of a health service. If the access was good, it would encourage the mothers to perform a health service, especially Pap Smear test.

\section{The relationship between family support and Pap Smear utilization}

The result of this study showed that there was a significant relationship between family support and Pap Smear utilization. Family support was related to Pap Smear utilization through perception on quality of health care. This study is consistent with a study by Purba (2011) which stated that an important factor in encouraging the mothers to perform test of early detection of cervical cancer was the closest people which were husband and family.

This study is consistent with a study by Kinanti (2012) which stated that there was a relationship between family support and the implementation of Pap Smear on reproductive age couple (RAC) in Pustang Gading Housing Semarang in 2012.

Family was a reinforcing factor that can affect WRA behavior. More husband mobility also help them to get information about cervical cancer and Pap Smear from their work environment. The support given by the family or husbands was positive response if the mothers invited discussion on women's health issues, two of them was cervical cancer and Pap Smear. Families who responded well would be followed by the provision of financial support for the cost of a Pap smear test, and the husband/ family expressed no objection when the mothers asked to be taken to the Pap Smear test. Most of the supportive husband would have the initiative to motivate the mothers to conduct Pap Smear test.

Based on the result of the study, it was showed that there was patriarchal culture in the society that was suspected to be the cause of the mothers to not conduct Pap Smear test even though she has a good education and work. This indicated the existence of cultural values that have changed the perception and behavior of mothers in making decisions. Mothers felt that every decision taken should be based on the husband's decision. Mothers who did not get support from their husbands felt that their husbands did not know about women's health issues. Similarly, mothers who have a positive attitude would not do a Pap Smear test if they did not get positive supports from their husband. As long as the mother did not complain about certain symptoms, then the husbands would think that the mothers were healthy.

Based on the result of this study, the researcher can concluded that if the mothers have awareness and interest in the Pap Smear from themselves and get the support from their husbands/families (emotional support, real support and information/knowledge support) it can significantly increase the maternal desire to perform pap smear test.

6. The relationship between peer support and Pap Smear utilization

The result of this study showed that there was an indirect positive relationship between peer groups and Pap Smear utilization. This study is consistent with a study by Sri Wahyuni (2013) which stated that peer group support was related to the behavior of early detection of cervical cancer.

From the questionnaires used in this study, it was showed that most of them assumed that WRA often did association with peers, and in the forum WRA did a lot of ideas exchange with each other. WRA claimed that they got many information and recommendations about health from their friends, and most of WRA was 
accompanied by their friends to do a consultation to health personnels in order to get information about Pap Smear. The invitation from peer simply affected the maternal decision to conduct the test, especially if the person who invited was a close friend, because usually the mother believed in the stories of their peers.

This study is consistent with a study by Parapat (2016) which stated that many mothers who eventually decided to do the test after being told by the their friends who invite them to conduct the test, therefore, the mothers actually did Pap Smear test.

Based on the results of this study, it can be concluded that peer groups can provided support and motivation to change the perception of Pap Smear, the quality of health care, and cervical cancer, therefore, this can provide support for the mothers to perform early detection of cervical cancer. The supports can be in the form of emotional support including an attentive expression, instrumental support including material support, and informational support.

\section{The relationship between health personnel and Pap Smear utilization}

The result of this study showed that there was a relationship between health personnel and Pap Smear utilization. The proportion of WRA who received good support from health personnel (62.5\%) was greater to perform Pap Smear than WRA who have lack of support from health personnel (27.5\%).

Based on the results of the study above, it can be seen from the support of health personnel in research subjects' point of view which was quite good, due to the active role of health personnel in providing health education about Pap Smear test, and it helped the research subjects to know the importance of early detection of cervical cancer test. The result of this study was in line with Rohmawati (2010), who stated that in a population, the support from health personnel was related to maternal behavior in Pap Smear test. Romadani (2014) also stated that lack of support from health personnel became a great factor on the delay of early detection of cervical cancer.

According to Bascommetro (2009), when a person was important to mothers, then the mothers tend to agree and did what that person was saying or doing. These important people were often referred to as reference groups, among others; teachers, religious scholars, customary chiefs (tribes), headman, and the like. Health personnel was a source of health information and in this case was Pap Smear test.

This study is consistent with a study by Sakanti (2007) which stated that women who were suggested by health personnel to conduct health check up tend to have a strong desire to conduct such tests.

To increase the coverage of the Pap Smear service, it can also be done by inviting the mothers to conduct Pap Smear test. Because based on the experience, the majority of WRA were willing to conduct Pap Smear test if they were invited by the officer or health cadre.

\section{REFERENCES}

Ali M, Asrori M (2014). Metodologi dan Aplikasi Riset Pendidikan. Jakarta : Bumi Aksara.

Arum SP (2015). Stop Kanker Serviks. Yogyakarta: Notebook.

Bascommetro (2009). Konsep Perilaku Kesehatan. http://www.bascommetro.com/2009/05/konsep-perilakukesehatan.html. Diakses o8 Januari 2018 jam 19.40WIB. 
Bustan (2007). Epidemiologi Penyakit Tidak Menular. Jakarta: Rineka Cipta.

Candraningsih (2011). Hubungan Tingkat Pengetahuan WUS Tentang Kanker Serviks dengan Praktek Deteksi Dini Kanker Serviks di BPS Is Manyaran Semarang. Jurnal Penelitian.

Depkes RI (2007). Pedoman Penemuan dan Penatalaksanaan Penyakit Kanker. Jakarta.

(2009). Pencegahan Kanker Leher

Rahim dan Kanker Payudara.Jakarta.

Dewi (2010). Teori dan Pengukuran Pengetahuan, Sikap dan Perilaku Manusia. Yogyakarta : Nuha Medika.

Handoko BS (2011). Manajemen Pemasaran-Analisis Perilaku. Konsumen. Yogyakarta : BPFE.

Linadi KE (2013). Dukungan Suami Mendorong Keikutsertaan Pap Smear Pasangan Usia Subur (PUS) di Perumahan Pucang Gading Semarang. Jurnal Kesehatan Reproduksi, 4, 61-71.

Mursyida RF (2012). Kepuasan Ibu Hamil Dan Persepsi Kualitas Pelayanan Antenatal Care Di Puskesmas Tanjung Kabupaten Sampang Madura. Media Kesehatan Masyarakat Indonesia, 11(2).

Murti B (2013). Desain dan Ukuran Sampel Untuk Penelitian Kuantitatif dan Kualitatif di Bidang Kesehatan. Yogyakarta: Gadjah Mada University Press.

Ni Ketut M (2013). Hubungan karakteristik pengetahuan dan sikap wanita usia subur dengan tindakan pemeriksaan pap semar di Puskesmas Sukawati II. Universitas udayana denpasar. Tesis. FKM Universitas Udayana.

Parapat FT (2016). Faktor Faktor yang Berhubungan dengan Perilaku Deteksi Dini Kanker Leher Rahim Metode Inspeksi Visual Asam Asetat di Puskesmas Candiroto Kabupaten Temanggung. Jurnal Kesehatan Masyarakat. Volume 4, Nomor 4.

Purba EM (2011). Faktor-Faktor yang Berhubungan dengan Pemeriksaan Pap smear pada Pasangan Usia subur (PUS) di Puskesmas Belawan Kota Medan Tahun 2011. Skripsi: FKMUI.

Rasjidi I (2008). Modalitas Deteksi Dini Kanker Serviks. Jakarta: Sagung Seto. (2009). Deteksi Dini Pencegahan Kanker pada Wanita. Jakarta: Sagung Seto.

(2009). Epidemiologi Kanker Serviks. Indonesian Journal of Cancer, III, 103-108.

Riskesdas (2010). Laporan Nasional Riset Kesehatan Dasar. Jakarta: Badan Penelitian dan Pengembangan Dasar.

Rohmawati I (2011). Faktor - Faktor yang Berhubungan dengan Perilaku Wanita Usia Subur dalam Deteksi Dini Kanker Servik dengan Metode IVA (Inspeksi Visual Dengan Asam Asetat) Di Wilayah Kerja Pusksesmas Ngawen I Kabupaten Gunung Kidul Tahun 2011. Skripsi. Jakarta, FKMUI.

Sakanti A (2007). Faktor-faktor yang Berhubungan dengan Perilaku Pemeriksaan Pap Smear pada Wanita Usia Subur di Puskesmas Kecamatan Makasar Tahun 2007. Jakarta, FKM UI.

Septadina IS (2015). Upaya Pencegahan Kanker Serviks Melalui Peningkatan Pengetahuan Kesehatan Reproduksi WanitaJurnal Pengabdian Sriwijaya, 223.

Susanti I (2010). Hubungan usia pertama kali berhubungan seksual dan jumlah pasangan seksual dengan kejadian lesi pra-kanker leher rahim pada wanita yang melakukan deteksi dini menggunakan metode inspeksi visual dengan asam asetat (IVA) di 
Journal of Health Promotion and Behavior (2017), 2(4): 359-370

https://doi.org/10.26911/thejhpb.2017.02.04.08

Puskesmas cikampek, Pedes, dan

tahun 2009-2010. Tesis. Jakarta.

Kota Baru Kabupaten Karawang 